bodies, and subsequent counselling, did not, however, alter the women's original intention. When the pregnancy was wanted the desire to have the baby overrode all other considerations. Many women were influenced by their lack of clinical illness and a belief that there was a low risk to the child, gained from local experiences and newspaper reports. The early experience locally has been unusually favourable, and as this changes so also may the perception of risk and the number of terminations.

The advantage of our study is that it was population based and hence independent of any particular source of recruitment. Like studies in New York ${ }^{3}$ (A Sunderland et al fourth international conference on AIDS, Stockholm, 1988; abstract No 6607), it shows that many women with HIV infection do not see this as a reason to terminate a wanted pregnancy. Whether this will remain true when clinical illness in women and babies is more apparent, or when women with different risk factors become pregnant, is being studied.

This study was supported by grant number R922055 from the Medical Research Council. We are grateful to Miss Barbara Hamilton for help with computing, Miss Lorne Kitchin for secretarial help, and Dr Robin Prescott for statistical advice.

1 Johnstone FD, MacCallum LR, Brettle RP, Burns SM, Peutherer JF. Testing for HIV in pregnancy: 3 years' experience in Edinburgh city. Scott Med $\mathcal{F}$ (in press)

2 Johnstone FD, MacCallum L, Brettle R, Inglis JM, Peutherer JF. Dies infection with HIV affect the outcome of pregnancy? Br. Med f 1988;296:467. Selwyn PA, Carter RJ, Schoenbaum EE, et al. Knowledge of HIV antibody status and decision to continue or terminate pregnancy among intravenous drug users. FAMA 1989;261:3567-571.

Accepted 17 Octoher 1989

\section{Lingual cellulitis causing upper airways obstruction in neutropenic patients}

\author{
O P Smith, H G Prentice, G M Madden, \\ B Nazareth
}

Royal Free Hospital,

London NW3 2QG

O P Smith, MRCP, registrar in haematology

H G Prentice, FRCP, consultant in haematology

G M Madden, FRCS, registrar in ear, nose, and throat surgery B Nazareth, MRCP, registrar in microbiology

Correspondence to: $\mathrm{Dr}$ Smith.

BrMed f 1990;300:24 gency insertion of a laryngotomy tube.

\section{Case reports}

Case 1-A 46 year old man with acute myeloblastic
Lingual cellulitis is extremely rare. When it develops in neutropenic patients the inflammation and associated swelling of soft tissue can advance so quickly that a prompt operation and medical treatment are required to secure the airway. We report on two immunocompromised patients in whom lingual cellulitis resulted in obstruction of the upper airways that required emerleukaemia underwent autologous bone marrow transplantation at this hospital. Six days later, while pancytopenic (haemoglobin concentration $100 \mathrm{~g} / 1$, white cell count $<0 \cdot 1 \times 10^{\circ} / 1$, platelet count 40 $\left.\times 10^{\circ} / 1\right)$, he became feverish $\left(38.4^{\circ} \mathrm{C}\right)$ and had oral discomfort. Over the next six hours his tongue enlarged greatly, preventing him from swallowing and speaking and causing difficulty with breathing. Computed axial tomography showed severe oedema of the soft tissue of the tongue. A laryngotomy tube was inserted through the cricothyroid membrane and intravenous penicillin and metronidazole were started. Forty eight hours later mixed viridans streptococci were isolated from blood cultures and intravenous amikacin was added to his treatment. One of the organisms isolated was a nutritional variant exhibiting satellite growth around another streptococcus that was subsequently identified as Streptococcus sanguis. The size of the tongue decreased rapidly, and the laryngotomy tube was removed after a further 24 hours.

Case 2-A 47 year old woman was receiving treatment for aplastic anaemia induced by gold (haemoglobin concentration $67 \mathrm{~g} / \mathrm{l}$, white cell count $0.5 \times 10^{9} / \mathrm{l}$, platelet count $46 \times 10^{\%} / 1$ with $20 \%$ neutrophils). Two days after admission she became feverish $\left(38.9^{\circ} \mathrm{C}\right)$ and developed massive swelling of the soft tissue on the right side of her tongue. Computed axial tomography showed oedema of the soft tissue extending posteroinferiorly into the floor of the mouth. Two hours later her tongue obstructed her airway and a laryngotomy tube was inserted as in case 1. Intravenous benzylpenicillin, amikacin, and metronidazole were started. Forty eight hours later the patient's temperature was normal, her tongue had returned to normal size, and the laryngotomy tube was removed and the stoma allowed to close. Klebsiella pneumoniae sensitive to amikacin had previously been isolated from throat swabs and grown from blood cultures and mouth swabs taken at the onset of the illness.

\section{Comment}

Lingual cellulitis precipitated by invasive bacterial infection is extremely rare, and no cases have been reported previously, although lingual swelling due to haemorrhage has been documented. ${ }^{1-3}$ In our profoundly neutropenic patients lingual cellulitis probably resulted from minor local trauma followed by infection with organisms in the mouth. The mixed infection in case 1 enabled the nutritionally variant streptococcus to be recognised early and amikacin added to the antibiotic regimen. Data on penicillin tolerance in cultured nutritionally variant streptococcus ${ }^{4}$ and clinical observations on patients with endocarditis suggest that all patients should receive combination treatment.

We inserted a laryngotomy tube rather than perform a tracheostomy because we thought that the severe lingual swelling would present only a short term obstruction in the patients. The tube was a fast and effective means of securing the airway. Enhanced computed axial tomograms were also of great value in differentiating between soft tissue of the tongue and lingual haematoma secondary to thrombocytopenia. This allowed us to start antimicrobial treatment with some confidence at an early stage rather than use platelet replacement treatment. The absence of lingual swelling by the second day of treatment was further proof that the swelling was due to oedema of soft tissue rather than haemorrhage.

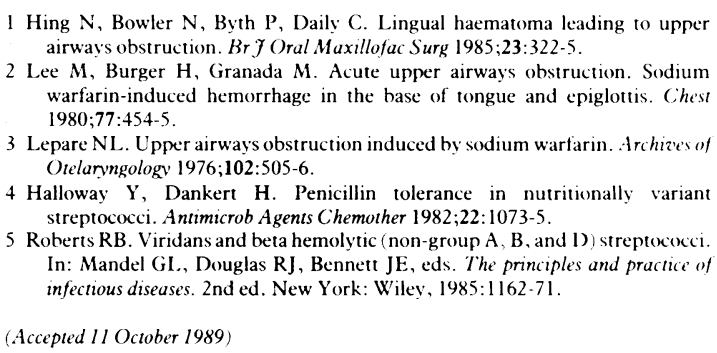
airways obstruction. Br Y Oral Maxillofac Surg 1985;23:322-5

2 Lee $M$, Burger H, Granada $M$. Acute upper airways obstruction. Sodium warfarin-induced hemorrhage in the base of tongue and epiglottis. Chest $1980 ; 77: 454-5$.

3 Lepare NL. Upper airways obstruction induced by sodium warfarin. Archives of Otelaryngologv 1976;102:505-6.

+ Halloway Y, Dankert H. Penicillin tolerance in nutritionally variant streptococci. Antimicrob Agents Chemother 1982;22:1073-5.

5 Roberts RB. Viridans and beta hemolytic (non-group A, B, and 1) streptococi. In: Mandel GL, Douglas RJ, Bennett JE, eds. The principles and practice of infectious diseases. 2nd ed. New York: Wiley, 1985:1162-71.

(Accepted 11 October 1989)

\section{Correction}

Bronchodilator effect of atrial natriuretic peptide in asthma An authors' error occurred in this short report by Dr G Hulks and others (28 October, pp 1081-2). The units for plasma atrial natriuretic peptide concentrations should have read pmol/l, not $\mathrm{nmol} / \mathrm{l}$ as published. 